\title{
Influence of Foliar Application of Benzyl Adenine and Nutrients on Growth and Yield of Transplanted Ginger (Zingiber officinale rosc.) under Hill Zone of Karnataka
}

\author{
Rani Jayadurga Nayak ", C. S. Ravi, M. Ganapathi, M. Shivaprasad and H. R. Bhoomika
}

Department of Plantation, Spices, Medicinal and Aromatic Crops, University of Agricultural and Horticultural Sciences, Shivamogga, College of Horticulture, Mudigere-577132, India

*Corresponding author

\section{A B S T R A C T}

\begin{tabular}{l} 
K e y w o r d s \\
$\begin{array}{l}\text { Transplanted } \\
\text { ginger, Clumps, } \\
\text { RDF, Benzyl } \\
\text { adenine, } \\
\text { Pseudostem, } \\
\text { Rhizome }\end{array}$ \\
\hline Article Info \\
\hline $\begin{array}{l}\text { Accepted: } \\
\text { 15 August } 2020 \\
\text { Available Online: } \\
\text { 10 September } 2020\end{array}$ \\
\hline
\end{tabular}

\section{Introduction}

Ginger (Zingiber officinale Rosc.) is ancient spice crop of India and it is a herbaceous perennial plant of monocotyledon belonging to family Zingiberaceae. It is assumed to have been originated from South East Asia probably India or China (Bailey, 1949). Ginger is a rhizomatous spice cum medicinal plant containing appreciable amount of moisture (81 \%), carbohydrates (12\%), protein $(2.3 \%)$, minerals $(1.3 \%)$, fiber $(2.5$ $\%)$ and fat (1 \%) (Swaminathan, 1974).
Among many essential oil components, gingerol (23-25\%) and shagoal (18-19\%) are the major compounds responsible for the characteristic pungency of rhizome.

India is the leading producer of ginger and Indian ginger is known for its superior quality in the International spice market. In India, the area under cultivation of ginger is about 1.60 lakh hectare with annual production of 11.18 lakh tones (Anon., 2018). Nearly 10-15 per cent of Indian ginger is exported to 50 countries around the world. In India, ginger is 
commercially cultivated through conventional method of planting where, seed rhizomes are broken into small fragments weighing 30-35 g with $2.5-5.0 \mathrm{~cm}$ length having one or two viable eye buds. This conventional method of propagation has some demerits such as requirement of large quantity of quality seed rhizomes (1500-1800 kg / ha), more cost of production due to higher seed rhizome rate as well as cost of rhizomes and long juvenile phase (Prashanth et al., 2018). To overcome these problems, transplanting method of cultivation is in vogue where single bud rhizomes are used to raise the plants in protrays (Thapa et al., 2017).

In protray technique, as small bit (about $5 \mathrm{~g}$ ) of rhizome with single viable eye bud are used for multiplication and usually only one sprout are available at the time of transplanting and to increase the more number of tillers per clump which is directly related to productivity of the crop, the growth regulators such as cytokinins are used. In general, the Plants need 17 essential nutrient elements to complete its life cycle. Among major nutrient elements, ginger is more responsive to nitrogen $(\mathrm{N})$ and potassium $(\mathrm{K})$. An adequate supply of nitrogen $(\mathrm{N})$ is highly essential for growth and better productivity as it is an indispensable constituent of nucleic acid and protein.

Phosphorus is the most important nutrient element in the production of rhizome as it plays a vital role in the breakdown of carbohydrate for the release of energy. Potassium is often described as a quality element for crop production. It indirectly improves utilization of nitrogen and protein formation, thereby increases the size of fingers, yield and oleoresin content in ginger. Among micronutrients, zinc $(\mathrm{Zn})$ and boron (B) play a major role in uptake of macro and micronutrients and also increases disease resistance and quality of ginger.
In Karnataka, ginger is also cultivated in hilly areas where, continuous and heavy down pour makes the soils vulnerable to leaching and fixation of nutrients. In order to meet the nutrient requirement and to increase the fertilizer use efficiency foliar application is recommended.

\section{Materials and Methods}

The experiment was conducted at Zonal Agricultural and Horticultural Research Station (ZAHRS), Mudigere during 2019-20. The ginger plants were raised in protrays containing media comprising of coco peat and vermicompost in the ratio $3: 1$. One month old plants were transplanted to raised beds. The experiment was laid out in Randomized Complete Block Design (RCBD) with twelve treatments and three replications. The individual plot size was kept $1.5 \times 1.2 \mathrm{~m}$. The ginger plants were spaced at $30 \times 30 \mathrm{~cm}$. The growth regulator (Benzyl adenine), macronutrients (19:19:19 and urea) and micronutrients $\left(\mathrm{ZnSO}_{4}, \mathrm{FeSO}_{4}\right.$ and borax) were used for foliar application. The micronutrients mixture used was Micnelf (MS-32) which comprises of iron (Fe-2.0\%), manganese (Mn-1.0\%), zinc (Zn-3.0 \%), copper $(\mathrm{Cu}-0.5 \%)$ and boron $(\mathrm{B}-0.5 \%)$. The treatment details $100 \%$ RDF (NPK) as soil application $\left(\mathrm{T}_{1}\right), 100 \% \mathrm{RDF}(\mathrm{NPK})$ as soil application + BA spray at $25 \mathrm{ppm}\left(\mathrm{T}_{2}\right), 100 \%$ $\mathrm{RDF}(\mathrm{NPK})$ as soil application + BA spray at $50 \mathrm{ppm}\left(\mathrm{T}_{3}\right), 100 \% \mathrm{RDF}(\mathrm{NPK})$ as soil application + BA spray at $75 \mathrm{ppm}\left(\mathrm{T}_{4}\right), 90 \%$ $\mathrm{RDF}(\mathrm{NPK})$ as soil application $+10 \% \mathrm{RDF}$ (NPK) as foliar spray $\left(\mathrm{T}_{5}\right), 80 \% \mathrm{RDF}(\mathrm{NPK})$ as soil application $+20 \%$ RDF (NPK) as foliar spray $\left(\mathrm{T}_{6}\right), 70 \% \mathrm{RDF}(\mathrm{NPK})$ as soil application $+30 \% \mathrm{RDF}(\mathrm{NPK})$ as foliar spray $\left(\mathrm{T}_{7}\right), 100 \%$ RDF (NPK) as soil application + foliar spray of micronutrients $\left(\mathrm{ZnSO}_{4}, \mathrm{FeSO}_{4}\right.$ and Borax $)$ at $0.25 \%$ each $\left(\mathrm{T}_{8}\right), 100 \%$ RDF (NPK) as soil application + foliar spray of micronutrients mixture at 0.25 
$\%\left(\mathrm{~T}_{9}\right), 90 \% \mathrm{RDF}(\mathrm{NPK})$ as soil application $+10 \%$ RDF (NPK) as foliar spray + micronutrients spray at $0.25 \%$ each $\left(\mathrm{T}_{10}\right), 80$ $\%$ RDF (NPK) as soil application $+20 \%$ $\mathrm{RDF}(\mathrm{NPK})$ as foliar spray + micronutrients spray at $0.25 \%$ each $\left(\mathrm{T}_{11}\right)$ and $70 \% \mathrm{RDF}$ (NPK) as soil application $+30 \% \mathrm{RDF}(\mathrm{NPK})$ as foliar spray + micronutrients spray at 0.25 $\%$ each $\left(\mathrm{T}_{12}\right)$. The growth regulator solution was prepared by dissolving required quantity of Benzyl adenine with little quantity of solvent (ethanol) and volume made up by adding distilled water as per the treatments. First foliar spray was carried out after 15 days after transplanting when the crop was better established to field conditions. The prepared growth regulator and nutrients solution was sprayed to each treatment. Totally three sprays (15, 45 and 75 days after transplanting) were given using hand sprayer at 30 days intervals during the period of experimentation. Observations on different growth and yield attributes were recorded from five randomly selected plants from each plots. Rhizome yield per hectare was calculated on the plot yield basis. Statistical analysis of the data was done as per method suggested by Panse and Sukhatme (1967).

\section{Results and Discussion}

The data recorded on growth attributes are furnished in Table 1. At 180 DAT (before senescence) the maximum pseudostem height and girth $(68.18$ and $1.10 \mathrm{~cm}$, respectively) was recorded in the clumps treated with $70 \%$ RDF (NPK) as soil application $+30 \% \mathrm{RDF}$ (NPK) as foliar spray + micronutrients spray at $0.25 \%$ each $\left(\mathrm{T}_{12}\right)$. While, minimum pseudostem height and girth (54.69 and 0.87 $\mathrm{cm}$, respectively) was recorded in $\mathrm{T}_{1}$ (Control). The positive effect of the nutrient on pseudostem height and girth might be due to the balanced nutrition of macro and micronutrients coupled with better fertilizer use efficiency enhanced the photosynthetic rate and other metabolic processes lead to increase in various plant metabolites responsible for cell multiplication and enlargement. These results are in conformity with the findings of Singh and Dwivedi (2007) with foliar application of zinc and iron and Shadap and Pariari (2016) with foliar application of zinc in ginger and Hnamte et al., (2018) in turmeric with combined application of boron and zinc.

The maximum number of tillers per clump (21.73), number of leaves per clump (233.30), leaf length $(26.33 \mathrm{~cm})$ and leaf breadth $(2.66$ $\mathrm{cm})$ was recorded in $\mathrm{T}_{4}[100 \% \mathrm{RDF}$ (NPK) as soil application + BA spray at $75 \mathrm{ppm}]$ at 180 DAT. While, least number of tillers per clump (15.92) number of leaves per clump (175.48), leaf length $(20.14 \mathrm{~cm})$ and leaf breadth $(2.33 \mathrm{~cm})$ was recorded in $\mathrm{T}_{1}$ (Control). The increase in these parameters in BA treated plants might be due to the fact that, Benzyl adenine promotes cell division and shoot differentiation which accelerated photosynthesis, phytohormone synthesis and metabolic processes which induced the plant growth by increasing number of leaves per clump in turn which increased the leaf length and breadth. The conclusions drawn by Sengupta et al., (2008) with application of ethrel, Pariari et al., (2018) with CCC spray in ginger; Anmoldeep et al., (2016) with NAA spray and Venugopal and Pariari (2017) with $\mathrm{GA}_{3}$ spray in turmeric support the present findings.

The maximum total chlorophyll content (57.09 SPAD units) was recorded in $\mathrm{T}_{12}[70$ $\%$ RDF (NPK) as soil application + $30 \%$ $\mathrm{RDF}$ (NPK) as foliar spray + micronutrients spray at $0.25 \%$ each]. While, minimum total chlorophyll content (48.18 SPAD units) was recorded in $\mathrm{T}_{1}$ (control). The increase in total chlorophyll content might be due to the optimum supply of micronutrients such as zinc, boron and iron which accelerates the 
chlorophyll synthesis. Similar results have been quoted by Jirali et al., (2007) with foliar application of zinc in turmeric; Besma et al., (2011) with potassium nitrate spray in potato.

Table.1 Effect of foliar application of Benzyl adenine and nutrients on growth parameters at 180 DAT in transplanted ginger

\begin{tabular}{|c|c|c|c|c|c|c|c|}
\hline Treatment & $\begin{array}{c}\text { Pseudostem } \\
\text { height }(\mathbf{c m})\end{array}$ & $\begin{array}{c}\text { Pseudostem } \\
\text { girth } \mathbf{( c m )}\end{array}$ & $\begin{array}{c}\text { Number of } \\
\text { tillers per } \\
\text { clump }\end{array}$ & $\begin{array}{c}\text { Number of } \\
\text { leaves per } \\
\text { clump }\end{array}$ & $\begin{array}{c}\text { Leaf } \\
\text { length } \\
\text { (cm) }\end{array}$ & $\begin{array}{c}\text { Leaf } \\
\text { breadth } \\
\text { (cm) }\end{array}$ & $\begin{array}{c}\text { Chlorophyll } \\
\text { content } \\
\text { (SPAD units) }\end{array}$ \\
\hline $\mathbf{T}_{\mathbf{1}}$ & 54.69 & 0.87 & 15.92 & 175.48 & 20.14 & 2.33 & 48.18 \\
\hline $\mathbf{T}_{\mathbf{2}}$ & 58.31 & 0.92 & 19.36 & 219.45 & 22.03 & 2.49 & 51.26 \\
\hline $\mathbf{T}_{\mathbf{3}}$ & 60.13 & 0.89 & 20.19 & 221.89 & 23.24 & 2.62 & 50.72 \\
\hline $\mathbf{T}_{\mathbf{4}}$ & 64.52 & 0.95 & 21.73 & 233.30 & 26.33 & 2.66 & 53.33 \\
\hline $\mathbf{T}_{\mathbf{5}}$ & 60.17 & 1.05 & 19.04 & 194.22 & 22.46 & 2.45 & 52.64 \\
\hline $\mathbf{T}_{\mathbf{6}}$ & 62.46 & 1.07 & 18.39 & 199.78 & 23.21 & 2.51 & 53.04 \\
\hline $\mathbf{T}_{\mathbf{7}}$ & 63.85 & 0.99 & 19.67 & 201.70 & 25.17 & 2.35 & 54.93 \\
\hline $\mathbf{T}_{\mathbf{8}}$ & 56.24 & 0.91 & 16.28 & 184.67 & 21.73 & 2.40 & 52.71 \\
\hline $\mathbf{T}_{\mathbf{9}}$ & 58.33 & 0.96 & 18.17 & 193.89 & 22.42 & 2.46 & 53.44 \\
\hline $\mathbf{T}_{\mathbf{1 0}}$ & 60.95 & 0.93 & 17.24 & 209.11 & 23.09 & 2.34 & 54.17 \\
\hline $\mathbf{T}_{\mathbf{1 1}}$ & 66.54 & 1.09 & 19.78 & 214.34 & 24.46 & 2.43 & 55.11 \\
\hline $\mathbf{T}_{\mathbf{1 2}}$ & 68.18 & 1.10 & 20.41 & 223.55 & 24.68 & 2.53 & 57.09 \\
\hline $\mathbf{S . ~ E m ~} \mathbf{E}$ & $\mathbf{0 . 8 9}$ & $\mathbf{0 . 0 1}$ & $\mathbf{0 . 5 8}$ & $\mathbf{3 . 3 3}$ & $\mathbf{0 . 6 7}$ & $\mathbf{0 . 0 5}$ & $\mathbf{0 . 7 1}$ \\
\hline $\mathbf{C D}$ @ 5\% & $\mathbf{2 . 6 4}$ & $\mathbf{0 . 0 3}$ & $\mathbf{1 . 6 9}$ & $\mathbf{9 . 7 8}$ & $\mathbf{1 . 9 8}$ & $\mathbf{0 . 1 5}$ & $\mathbf{2 . 0 8}$ \\
\hline
\end{tabular}

Table.2 Variation in rhizome characteristics and its yield as influenced by foliar application of Benzyl adenine and nutrients in transplanted ginger

\begin{tabular}{|c|c|c|c|c|c|c|c|c|c|c|}
\hline \multirow[t]{2}{*}{ Treatment } & \multirow{2}{*}{$\begin{array}{l}\text { Rhizome } \\
\text { length } \\
\text { (cm) }\end{array}$} & \multirow{2}{*}{$\begin{array}{c}\text { Rhizome } \\
\text { breadth } \\
\text { (cm) }\end{array}$} & \multirow{2}{*}{$\begin{array}{l}\text { Number } \\
\text { of } \\
\text { primary } \\
\text { fingers }\end{array}$} & \multirow{2}{*}{$\begin{array}{l}\text { Number } \\
\text { of } \\
\text { secondary } \\
\text { fingers }\end{array}$} & \multirow{2}{*}{$\begin{array}{c}\text { Total } \\
\text { number } \\
\text { of } \\
\text { fingers }\end{array}$} & \multirow{2}{*}{$\begin{array}{l}\text { Primary } \\
\text { finger } \\
\text { length } \\
(\mathrm{cm})\end{array}$} & \multirow{2}{*}{$\begin{array}{c}\text { Primary } \\
\text { finger } \\
\text { circumference } \\
\text { (cm) }\end{array}$} & \multicolumn{3}{|c|}{ Fresh rhizome } \\
\hline & & & & & & & & $\begin{array}{l}\text { Yield } \\
\text { per } \\
\text { clump } \\
(\mathrm{g})\end{array}$ & $\begin{array}{l}\text { Yield } \\
\text { per } \\
\text { plot } \\
(\mathrm{kg})\end{array}$ & $\begin{array}{l}\text { Yield per } \\
\text { hectare } \\
(t)\end{array}$ \\
\hline $\mathbf{T}_{1}$ & 11.43 & 11.64 & 4.80 & 16.47 & 21.27 & 7.91 & 5.93 & 488.47 & 3.62 & 16.75 \\
\hline $\mathbf{T}_{2}$ & 13.58 & 14.29 & 5.13 & 18.40 & 23.40 & 8.11 & 6.31 & 830.80 & 4.33 & 20.05 \\
\hline $\mathbf{T}_{3}$ & 14.65 & 15.07 & 5.80 & 19.27 & 25.73 & 8.49 & 6.35 & 851.53 & 4.45 & 20.58 \\
\hline $\mathbf{T}_{4}$ & 16.93 & 16.54 & 7.60 & 22.07 & 29.67 & 10.53 & 6.49 & 894.67 & 4.60 & 21.27 \\
\hline $\mathbf{T}_{5}$ & 15.27 & 15.41 & 6.67 & 21.13 & 27.80 & 9.41 & 6.54 & 756.20 & 4.11 & 19.02 \\
\hline$T_{6}$ & 16.34 & 16.29 & 7.53 & 23.53 & 31.07 & 10.08 & 6.46 & 724.87 & 3.95 & 18.30 \\
\hline $\mathbf{T}_{7}$ & 17.88 & 16.92 & 8.27 & 24.27 & 32.60 & 11.21 & 7.14 & 905.13 & 5.57 & 25.77 \\
\hline$T_{8}$ & 13.21 & 14.08 & 6.80 & 17.00 & 23.80 & 8.84 & 6.25 & 552.93 & 3.68 & 17.05 \\
\hline$T_{9}$ & 14.23 & 13.85 & 6.33 & 20.67 & 26.87 & 8.87 & 6.41 & 665.40 & 3.84 & 17.77 \\
\hline $\mathbf{T}_{10}$ & 16.49 & 15.81 & 7.07 & 21.07 & 28.13 & 9.71 & 6.89 & 798.33 & 5.06 & 23.44 \\
\hline$T_{11}$ & 15.66 & 16.83 & 7.93 & 21.87 & 29.80 & 10.25 & 7.00 & 843.53 & 5.30 & 24.52 \\
\hline $\mathbf{T}_{12}$ & 18.08 & 17.54 & 8.20 & 22.20 & 30.53 & 11.78 & 7.38 & 913.13 & 5.79 & 26.80 \\
\hline S. Em \pm & 0.31 & 0.34 & 0.27 & 0.57 & 0.58 & 0.22 & 0.11 & 12.58 & 0.30 & 0.83 \\
\hline $\begin{array}{c}\text { C D @ } \\
5 \%\end{array}$ & 0.91 & 1.01 & 0.78 & 1.67 & 1.71 & 0.65 & 0.31 & 36.90 & 0.89 & 2.44 \\
\hline
\end{tabular}




\section{Rhizome characteristics}

The data recorded on rhizome characteristics and its rhizome yield is enumerated in Table 2. The maximum rhizome length $(18.08 \mathrm{~cm})$, rhizome breadth $(17.54 \mathrm{~cm})$ and primary rhizome length $(11.78 \mathrm{~cm})$ and circumference $(7.38 \mathrm{~cm})$ was recorded in the treatment $\mathrm{T}_{12}$ $[70 \%$ RDF (NPK) as soil application $+30 \%$ RDF (NPK) as foliar spray + micronutrients spray at $0.25 \%$ each]. While, the minimum rhizome length $(11.43 \mathrm{~cm})$, rhizome breadth $(11.64 \mathrm{~cm})$ and primary rhizome length $(7.91$ $\mathrm{cm})$ and circumference $(5.93 \mathrm{~cm})$ was recorded in $\mathrm{T}_{1}$ (Control).

The supply of macro and micronutrients in balanced form in all stages of crop growth might have resulted in increase of rhizome characteristics.

Among macronutrients, phosphorus has essential functions in plant life as it plays an important role in energy storage i.e. phosphate compound acts as "energy currency" within the plants. Similar variations in yield attributes were reported by Shadap and Pariari (2016) with zinc spray in ginger; Besma et al., (2011) with potassium spray in potato and Jobori and Hadithy (2014) with application of micronutrient mixture in potato.

The maximum number of primary (8.27), secondary fingers (24.27) and total number of fingers per rhizome (32.60) was recorded in $\mathrm{T}_{7}[70 \% \mathrm{RDF}$ (NPK) as soil application +30 $\%$ RDF (NPK) as foliar spray]. While, the lowest number of primary (4.80), secondary (16.47) and total number of fingers per rhizome (21.27) was recorded in $\mathrm{T}_{1}$ (Control).

This increase in number of fingers per rhizome might be due to balanced macro and micronutrients supply through foliar application which might have resulted in better assimilation of carbohydrates in rhizome. The present findings are in consonance with the Shadap and Pariari (2016) with zinc spray in ginger and Jobori and Hadithy (2014) with application of micronutrients mixture in potato.

\section{Fresh rhizome yield}

The maximum fresh rhizome yield per clump, per plot and per hectare $(913.13 \mathrm{~g}, 5.79 \mathrm{~kg}$ and $26.80 \mathrm{t}$, respectively) was recorded in $\mathrm{T}_{12}$ [70 \% RDF (NPK) as soil application $+30 \%$ RDF (NPK) as foliar spray + micronutrients spray at $0.25 \%$ each]. While, minimum fresh rhizome yield per clump, per plot and per hectare $(488.47 \mathrm{~g}, 3.62 \mathrm{~kg}$ and $16.75 \mathrm{t}$, respectively) was recorded in $\mathrm{T}_{1}$ (Control). The increased rhizome yield was might be due to better growth and development of the plant as supply of balanced macro and micro nutrients through foliar sprays. Nitrogen being the constituent of chlorophyll and protein which promoted the vegetative growth.

The total yield was directly influenced by increased photosynthesis rate has been reported with micronutrients spray in turmeric (Jirali et al., 2007). Among micronutrients, boron plays an major role in $\mathrm{pH}$ regulation, transport of minerals, cell expansion, cell wall structure integrity etc., Boron also increases translocation of metabolites towards storage structure (rhizome) ultimately leading to increase in overall rhizome yield. Similar findings were reported by Shadap and Pariari (2016) with zinc spray in ginger and Besma $e t$ al., (2011) with application of potassium in potato.

In conclusion from the results obtained in the present study, it is evident that the growth and yield attributes are significantly influenced by foliar application of Benzyl adenine and nutrients. The application of 70 per cent RDF 
(NPK) as soil application +30 per cent RDF (NPK) as foliar spray + micronutrients spray at 0.25 per cent each proved to be the best in terms of improved growth and yield attributes of transplanted ginger.

\section{References}

Anmoldeep, S., Walia, S. S., Rajendra, K. and Brar, A. S., 2016. Growth and productivity of turmeric (Curcuma longa L.) as influenced by different types of planting material and growth regulators. Indian J. Eco. 43(2): 593595.

Anonymous, 2018. Horticultural Statistics at a Glance. Horticulture Statistic Division, Department of Agricultural, Co-operation and Farmers Welfare. p. 143- 214.

Bailey, L. H., 1949, Manual of cultivated plants, $2^{\text {nd }}$ edition Mac Millan Company, New York.

Besma, B. D., Mounir, D. and Samia, A., 2011. Foliar potassium fertilization and its effect on growth, quality of potato grown under loamsandy soil and conditions. Int. J. Agric. Res. 10(1): $1-8$.

Hnamte, V., Chatterjee, R., Lungmuana and Patra, P. K., 2018. Influence of boron and zinc nutrition on growth, yield and quality of turmeric (Curcuma longa L.) in Gangetic alluvial soil of West Bengal. J. Crop and Weed. 14(1): 72-77.

Jirali, D. I., Hiremath, S. M., Chetti, M. B. and Patil, S. A., 2007. Biophysical, biochemical parameters, yield and quality attributes as affected by micronutrients in turmeric. Plant Archives. 7(2): 827-830.

Jobori, K. M., and Hadithy, S. A., 2014. Response of potato (Solanum tuberosum L.) to foliar application of iron, manganese, copper and zinc. Int. J. Agric. and Crop Sci. 7(7): 358363.

Panse, V. G., and Sukhatme, P. V., 1967.
Statistical methods for agricultural workers. Indian Council of Agricultural Research, New Delhi. pp. 155.

Pariari, A, Karthik, C. S. and Das, S., 2018. Studies on the influence of different plant growth regulators on growth, yield and quality of ginger (Zingiber officinale Rosc.) variety Nadia in Gangetic alluvial plains of West Bengal. Int. J. Chem. Studies. 6(1): 1640-1643.

Prashanth, D., Kandiannan, K., Srinivasan, V., Leela, N. K. and Anandaraj, M., 2018. Comparison of conventional and transplant production systems on yield and quality of ginger (Zingiber officinale). Indian J. Agri. Sci. 88(4): 615-620.

Sengupta, D. K., Maity, T. K. and Dasgupta, B., 2008. Effect of growth regulators on growth and rhizome production of ginger (Zingiber officinale Rosc.) in the hilly region of Darjeeling district. J. Crop and Weed. 4(2): 10-13.

Shadap, A. and Pariari, A., 2016. Effect of foliar sprays of micronutrients on the yield and quality of ginger (Zingiber officinale Rosc.). J. Crop and Weed. 12(3): 27-30.

Singh, S. P., and Dwivedi, D. K., 2007. Impact of zinc, boron and iron elements on yield and economics of ginger (Zingiber officinale Rosc.). Int. J. Agric. Sci. 3(1): 136-138.

Swaminathan, M., 1974. Essentials of food and nutrition, volume II, Mysore Printing and Publishing House, Mysore. pp. 484-485.

Thapa, A., Datta, S., Dey, A. N. and Baisare, P., 2017. Advances in propagation techniques in important spice crops. Int. J. Curr. Microbiol. App. Sci. 6(9): 1979-1985.

Venugopal, S., and Pariari, A., 2017. Effect of growth regulators on growth and yield of turmeric (Curcuma longa L.) varieties in Gangetic alluvial plains of West Bengal. Int. J. Agric. Sci., 9(15): 4104-4106.

\section{How to cite this article:}

Rani Jayadurga Nayak, C. S. Ravi, M. Ganapathi, M. Shivaprasad and Bhoomika, H. R. 2020. Influence of Foliar Application of Benzyl Adenine and Nutrients on Growth and Yield of Transplanted Ginger (Zingiber officinale rosc.) under Hill Zone of Karnataka. Int.J.Curr.Microbiol.App.Sci. 9(09): 1793-1798. doi: https://doi.org/10.20546/ijcmas.2020.909.224 